\title{
DEVELOPMENT OF FRANCHISING IN CROATIA OBSTACLES AND POLICY RECOMMENDATIONS
}

\section{Mirela Alpeza, Aleksandar Erceg, Sunčica Oberman Peterka}

(1) Faculty of Economics, J.J. Strossmayer University, Osijek, Croatia,

(2) Faculty of Economics, J.J. Strossmayer University, Osijek, Croatia,

${ }^{(3)}$ Faculty of Economics, J.J. Strossmayer University, Osijek, Croatia

MirelaAlpeza, PhD, Faculty of Economics J.J. Strossmayer University Gajev trg 7, 31000 Osijek, Croatia e-mail:malpeza@efos.hr

Article info Paper category: Preliminary paper Received: $4 \cdot 9 \cdot 2015$. Accepted: 6.11.2015. JEL M12, M21 


\begin{abstract}
Franchising is very popular growth model but despite the wide application of franchising in the developed countries of the world, its impact on the Croatian economy is still marginal. The purpose of this research is to identify the obstacles and challenges to a wider application of franchising in Croatia and generate policy recommendations for removing the identified obstacles. Obstacles and recommendations are identified on the basis of a conducted longitudinal qualitative research, the first phase of which was conducted in 2006, and second in 2014. The overall results of this research were presented in a form of PEST analysis and compared with the results of the 2006 research aiming to detect changes (improvements / deterioration) in individual areas of the research political, economic, legal and technologic factors of influence on the development of franchising in Croatia. Based on the detected changes, conclusions and policy recommendations were identified.The obstacles can be divided in two categories: franchising specific barriers and general business related obstacles for doing business in Croatia. Without removing most of these obstacles, it is unrealistic to expect high growth of franchising activities in Croatia in near future.
\end{abstract}

\title{
Keywords:
}

franchising, business model, obstacles, policy recommendations 


\section{DEFINING THE CONCEPT OF FRANCHISING}

According to the Seid (2002) franchising occurs when the franchisor licenses its brand and its operating methods to the franchisee that agrees to operate according to the terms of a franchise contract. Other authors give similar definitions of franchising, with emphasis on the legal relationship between the franchisor and the franchisee (Emmerson, 1990), economic category that offers a favorable combination of the economy of scale (Stanworth, 1991), trade or service mark (Spinelli et al., 2004), intellectual property package and franchise agreement (Mlikotin Tomic, 2000), or system of placing goods, services and technologies on the market (European Franchise Federation EFF, 2005). The franchise business model brings advantages and disadvantages to both sides of the business relationship. By using the franchise business model, the franchisor achieves faster growth with lower capital commitment and can have a potentially higher growth rate. Rapid growth enables achieving economy of scale with minimum investment where three main resources: managers, money and time, are provided by the franchisee (Shane, 2005; Maitland, 2000). As a disadvantage for franchisors and a source of potential conflicts Shane (2005) stated the issue of profits because the franchisor wants to achieve higher revenues through higher royalties, and the franchisees strive to maximize profits by keeping costs under control, which often causes lower sales volume, concentration of retail outlets in a particular area and lower investment in advertising and training. One of the biggest advantages of the franchise business model for the franchisee is that it provides a proven business model (Maitland, 2000) which guarantees recognition in the market. Maitland (2000) and Shane (2005) mention additional benefits: lower risk of failure, standard product and quality are offered through a validated business system, help in choosing a location, benefits from the franchisor's development program, and, ultimately, protection from the competition. Nieman and Barber (1987) state franchisor's excessive control and elements of risk in business operations as disadvantages of the franchise business model for the franchisee. Other authors cite the following weaknesses for the franchisee: poorly estimated ability to prosper within the system and a low threshold of tolerance for restriction of freedoms, that is, franchisor's business restrictions and control (Kukec, 2009), overdependence on the franchise system, reduced operating flexibility and exposure to factors that the franchisee cannot influence (Selnew, 1998). Castrogiovanni and Justis (1998: 170) stated that "franchising organizations differ from most others in three important respects: (1) geographic dispersal of organization units; (2) replication across units; and (3) joint ownership." They also noted that although some other organizational forms have one or two of the above characteristics, it is rare to see another organizational form with all three features. Compared to other growth models (licensing, authorized dealer, authorized agent, organic growth), franchising brings more benefits and less risk to both franchisor and franchisee. Franchising requires less capital commitment than 
the other models, has smaller business and financial risk, enables faster and more secure growth, needs smaller number of employees and enables highly motivated managers which run franchised locations (Stanworth and Purdy, 2002).

\section{THEORETICAL ANTECEDENTS}

The most commonly researched topic in the franchising field has been the reasoning behind using franchising as a growth model, comparing to organic growth and opening own locations. The two most important theories used for explanation of this phenomenon are resource scarcity theory and agency theory.

Resource scarcity theory identifies franchising as a mechanism for removing financial and managerial obstacles for company growth. This theory has become a widely accepted approach for explaining the tendency of companies to grow by using franchising. In this theory it is assumed that economy of scale is a significant determinant for the survival of the system in which franchisees provide capital and other resources, and companyowned locations are more profitable than locations operated by franchisees. Oxenfeld and Kelly (1969) explored the problem of the lack of franchisor's capital. It was found that companies use franchising business model to gain access to scarce resources (financial and managerial) in order to grow. In situations when companies are young and small, it is difficult for them to raise the necessary capital for the growth and expansion by using traditional financial market instruments and develop the talent needed to manage new locations on their own. Franchisees are a source of cheaper capital (franchise fees and royalties) that allow franchisor to grow. Later research on the franchise business model explored the scarcity of human capital (Norton, 1988) and managerial talent and knowledge of local market conditions (Combs and Castrogiovanni, 1994) as the crucial drivers for the use of franchising. Resource scarcity theory emphasizes the importance of age, company size, growth rate and the availability of capital as the key factors of impact when deciding on use of the franchise business model as a growth strategy (Gillis and Castrogiovanni, 2012). Rubin (1978) criticized the resource scarcity theory noting that franchising is an inefficient way of providing capital compared to traditional capital markets. Lafontaine and Kaufmann (1994) emphasized that, besides money and management of locations that are provided by the franchisee, franchising has the advantage in retention of control over company operations. Combs et al. (2011: 414) emphasized that "gaining access to franchisees' resources is an important advantage of franchising but, since franchising continues once resource scarcities are eliminated, there have to be other important aspects for implementation of franchising." The conducted research confirmed that most of the franchise systems have a dual structure they have their own and franchised locations.

Agency theory is another most commonly used approach in franchising research, focused on identifying the effectiveness of employees and managers in in- 
dependent franchise locations (Rubin, 1978; Shane, 1996). Based on the assumption that agents have their own interests and goals that differ from the objectives of the principal, the principal has to expend resources (agency costs) to ensure that agents act in its best interests. (Eisenhardt, 1989). Agency theory is focused on several issues: moral hazard cost control, freeride problem, and potential for a selection of quasirent (Rubin, 1978; Norton, 1988). Agency theory examines franchising as a mechanism for alignment and improvement of incentives between the principal company level and other locations (agents). Gillis and Castrogiovanni (2012,82) stated that "in franchising, risk neutral franchisors (principals) contract with risk adverse franchisees or managers (agents) to perform certain activities, such as running a franchise location in accordance with a standardized system of operating routines." Agency theory assumptions provide symmetrical explanation for the franchise business model. Balancing the advantages and disadvantages of franchise locations in comparison with their own locations determines in which direction the company will start to grow. Franchising is administratively efficient when high costs of supervision are in connection to ownership. Carney and Gedajlovic (1991) found that if the cost control amount is insignificant, the franchising model does not provide substantial contribution to business efficiency so in that situation company will opt for opening its own locations. Agency theory is based on comparison of costs associated with monitoring companyowned sites (distance between sites, local knowledge) and problems associated with franchising insufficient investment, freeride and contract negotiations. Besides the two mentioned theories, other commonly referenced theories in franchising research are: plural organization theory (Bradach, 1997), upperechelon theory, resources based theory (Combs et al., 2004), institutional theory (Shane and Foo, 1999), tournament theory, property rights theory and strategic deviance theory (Combs et al., 2011). Variety of different theoretical approaches to franchising imposes the need for further research on franchising issues and research implications.

\section{FRANCHISING AND ECONOMIC INFLUENCE WORLDWIDE}

Franchising is primarily seen as a method of distributing goods and services to the final consumer (Selnew, 1998). In addition to the method of distribution, franchising can be considered as an alternative way of forming the capital, as a catalyst for technological achievement of business objectives, and as an investment opportunity. Alon (2006) stated that franchising impacts economy among other through output and job creation, modernization of economy, development of entrepreneurship and increasing of capabilities and skills. Additionally Dwivedy (2002) noted that franchising influences transfer of technology and business methods and offer of quality products and services at reasonable prices. Castrogiovanni and Justis (1998: 170) stated that "the importance of franchising is expanding beyond domestic borders with franchising rapidly becoming the fastest growing form of business in the global economic 
system." The franchise business model is considered to be a driver of employment and development of entrepreneurship, and is determined by the method of successful business operations and an optimal number of employed in the franchise system. The franchisor has to develop its own sales team for development and support of the franchising network, aiming on maximizing profits, which ultimately increases the income and number of employees.

Today there are more than 28,000 different franchise systems in the world (EFF, 2010) that operate in one or more countries. The highest number of franchise systems is recorded in Asia and Europe, while Africa has the lowest number, but with a significant increase in recent years (Siggel et al., 2003). According to research conducted by the International Franchise Association (IFA) and the US Census Bureau (Mesenbourgh, 2010), there are more than 450,000 companies involved in franchising networks in the USA, with more than 7.9 million people directly employed and accounting for 1,300 billion US dollars sales of the 7,700 billion USD total in the USA. In Europe, franchise systems employ more than 2.5 million people and generate more than 145 billion USD (EFF, 2010). The leaders in franchising in Europe are France, Germany, Italy, United Kingdom and Spain. Asia, as the highest populated continent, represents an important franchising market. In China, there are currently more than 2,100 franchise systems operating in 120,000 locations, with more than 2.1 million people employed and having sales of over 30 billion USD. India has around 1,200 franchise systems with sales of 13.4 billion USD, which generated almost $1.5 \%$ of GDP in 2012. South African Republic is the franchise leader in Africa, with around 4,00 franchise systems, out of which almost $90 \%$ are domestic. The most developed franchising market in South America is Brazil, with around 2,100 franchising systems, 900,000 people employed and having 4,3 billion USD in sales. Australia has around 1,000 franchise systems in ๆ०,००० locations with around ๆ००,००० people employed and having sales of around 128 billion USD.

Franchising in Croatia started in 1969 when Diners Club Adriatic with headquarters in Zagreb started to operate as Diners Club International franchisee in the whole of the former Yugoslav market. The first substantial promotion of franchising as a way of doing business was done with McDonald's entering the Croatian market in the early 1990s. McDonald's established a company, McDonald's Hrvatska Ltd., and signed business agreements with key suppliers in Croatia. McDonald's presentations in cities where the franchisor sought franchisees generated great interest among potential franchisees and debates on the nature of the franchise agreement offered by McDonald's (Alon et al, 2010). Franchising contract is not defined in the Croatian legal system, and in practice commercial courts and lawyers apply European Franchise Code of Ethics as a foundation and guideline for concluding and terminating franchise agreements in Croatia (Glujic, 2008). A couple of years after McDonald's entered the Croatian market, several other franchisors appeared, such as Hungarian bakery franchise Fornetti and U.S. restaurant franchise Subway. At the 
end of 1990ties, a new wave of franchising development started in Croatia with arrival of fashion franchise systems (Esprit, Escada, Palmers, Terranova, Calzedonia).

Institutional support initiative for franchising development in Croatia started in 2003 when the first Franchising Centers in Osijek and Zagreb were founded. Soon after, Croatian Franchising Association started promoting franchising and organized the first Franchising Fair in Zagreb in 2003. All three organizations are principal reference points for getting information about franchising in Croatia and are also used for establishing contacts between potential franchisees and franchisors. According to the European Franchising Federation (EFF, 2010) there are 180 franchise systems in Croatia, out of which 25 are of Croatian origin (14\%). Franchise systems are operating in some 1,000 locations and employing around 16,500 people. Compared to Croatia, other transition countries have many more franchise systems, and, what is especially important to observe, a much higher share of domestic franchises: Poland $73 \%$, Hungary $70 \%$, and Slovenia 49\% (Table 1.). In 1990s transition countries have become an interesting market for international franchisors since differences in doing business were decreasing and there was increasing demand and brand recognition for products coming from the "Western world".

Table 1.: Comparison of franchising in Croatia and several European countries

\begin{tabular}{|l|r|r|r|r|r|}
\hline \multicolumn{1}{|c|}{ Country } & $\begin{array}{c}\text { Number of } \\
\text { franchises }\end{array}$ & $\begin{array}{c}\text { Number of } \\
\text { domestic } \\
\text { franchises }\end{array}$ & $\begin{array}{c}\text { Share of } \\
\text { domestic } \\
\text { franchises }\end{array}$ & $\begin{array}{c}\text { Number of } \\
\text { franchised } \\
\text { locations }\end{array}$ & $\begin{array}{c}\text { Number of } \\
\text { employed in } \\
\text { franchises }\end{array}$ \\
\hline Croatia & 180 & 25 & $14 \%$ & 1.000 & 16.500 \\
Hungary & 341 & 240 & $70 \%$ & 18.000 & 100.000 \\
Italy & 870 & 835 & $96 \%$ & 53.000 & 180.500 \\
Slovenia & 107 & 52 & $49 \%$ & 1.500 & 6.900 \\
Poland & 565 & 410 & $73 \%$ & 26.600 & 350.000 \\
France & 1.370 & 1.220 & $89 \%$ & 51.600 & 690.000 \\
\hline
\end{tabular}

Source: European Franchise Federation, 2010.

In 2010, in order to support the development of franchising in Croatia, Croatian Ministry of Entrepreneurship and Crafts initiated a pilot support program aimed at providing financial subsidy for the development of Croatian franchise systems. The program increased entrepreneurs' interest and promoted franchising as a way of growing the business as franchisors or as a way of entering the business as franchisees. Within this program Ministry of Entrepreneurship and Crafts awarded 12 grants to entrepreneurs, with the total amount of grants of $130,000 \mathrm{EUR}$, and the average grant amount of 11,000 EUR (Entrepreneurship Impulse, 2013). Despite the positive results, the support program for franchising development was not included in subsequent state granting schemes. 


\section{BARRIERS TO DEVELOPMENT OF FRANCHISING}

Previous research identified obstacles and barriers for development of franchising in different environments. Alon (2004) identified lack of managerial and entrepreneurial talent of the franchisor, lack of capital for international expansion, risk of political instability and insufficiently developed infrastructure as main obstacles that may affect the development of franchise business model. Fulop (2000: 40) noted that trends affecting the size and growth rate of the franchise industry are "the degree of economic activity; shift towards the service sector; rate of entry into franchising by established firms; and extent of crossborder franchising." Caffey (2009) identified complicated system of operations, high costs of starting business operations, weak company brand, lack of financial resources and necessary experience, and unresolved legal issues of the company as internal obstacles for franchising development. Obstacles are especially emphasized in countries where the franchise business model is relatively new, while in developed countries these barriers are less visible. This primarily refers to existence of supporting institutions and franchise associations that help companies that opt to use franchising as a method of growth. In transition economies, one can find substantial challenges and obstacles for franchising development. Sanghavi (1998: 38) stated that some of those obstacles include "incompatible business practices, infrastructural deficiencies, underestimated costs of imported ingredients, tariff barriers for input components, the absence or misjudgment of the required demand, lower purchasing power of the target group, investors, etc". Obstacles can be seen also in different sectors. DiazBernardo (2009: 61) mentioned three potential obstacles in hotel franchising development in Europe: "lack of potential franchisees with both the necessary skills and the financial resources needed, great concern about quality standards of potential franchisees and how to enforce the chain's quality standards in the franchisee's property, and litigation and other legal issues involved in franchise contract." Hoffman and Preble (2004) stated that political barriers have significant influence on franchising, which include concerns about economic stability and possible changes in political environments. Socioeconomic barriers also influence franchising growth in some countries through problems, such as inflation, low income and weak currency that may affect success of the franchise system. Technological barriers are also a significant element for franchising growth and they can be found in form of different regulations, sanitary measures and standards.

Previous research on franchising in Croatia (Alon at al., 2010) identified the main obstacles to the development of franchising as: insufficient legal regulations related to franchising, slow judicial system, mistrust, low interest of foreign franchisors to enter the Croatian market and, ultimately, low level of education on benefits and opportunities provided by franchising. According to Pavlin (2008), who conducted similar research in Slovenia, main obstacles to franchising are: increased competition in the market, lack of understanding of the franchising philosophy, turbulent environ- 
ment (transition time and the recession), absence of capital and financial resources, and a lack of legal experts specialized in the field of franchising. Alpeza et al. (2012) mentioned additional obstacles to the franchising expansion: problems of intellectual property protection, insufficient information about the franchise business model (fairs, books, magazines) and a lack of professional and fair conduct between entrepreneurs (franchisors and franchisees), which influences relationship in franchising. All the previously mentioned studies have identified a number of common problems that potential franchisors face in their countries when starting a franchise. The most commonly mentioned obstacles to franchise development in Croatia are inadequate knowledge about franchising, insufficient number of legal experts in franchising, lack of financial resources and knowledge about franchising among bank representatives. Previous research has yielded a number of recommendations which could resolve a part of the obstacles, especially at the macro level, affecting further development and use of the franchise business model in Croatia. This particularly applies to creation of legal framework for franchising, establishing a registry on franchising activity at national level and strengthening infrastructure support for the development of the franchise business model by educating key stakeholders associated with the franchise business model (bankers, lawyers, consultants). Based on the research conducted in 2012 among franchisors in Croatia, Erceg (2012) developed the model for increasing the number of franchise users (franchisors and franchisees) in Croatia.

Figure 1.: Model for increasing the number of franchise users

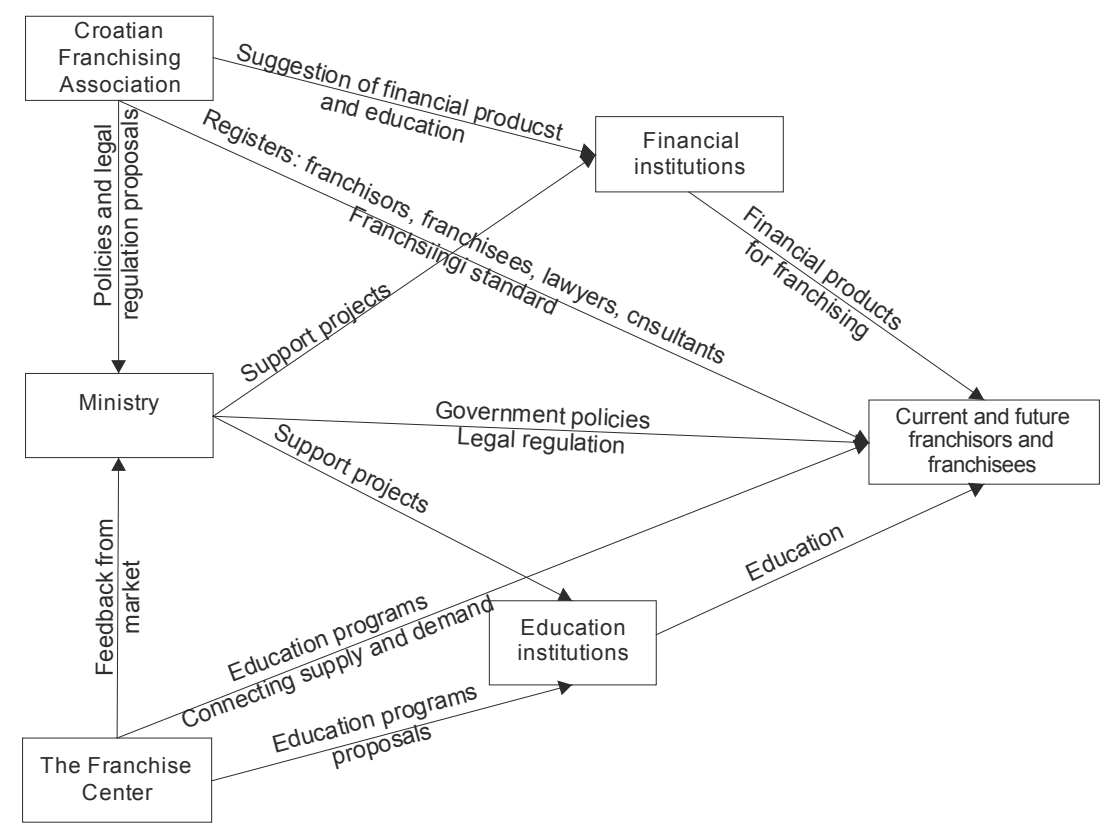

Source: Erceg (2012: 202). 
In his model Erceg identified the crucial role of the Croatian Franchising Association (CFA) in implementation of activities aimed at promotion and improvement of the franchising environment in Croatia. The model shows the influence that different stakeholders, such as the CFA, franchise centers, financial and educational institutions have on increasing the number of franchise users (both franchisors and franchisees). CFA should lead the process of promoting the use of franchising in Croatia. CFA should also aim its efforts towards the relevant ministry for enactment of legal framework for franchising and for creating franchising agreements. By creating educational programs, franchise centers act toward different education institutions in order to provide systematic education for potential franchisees and franchisors. By creating special financial products for franchising, financial institutions enable easier entry into franchising. The relevant ministry acts toward increasing the number of people included in franchising through adopting government policies, legal framework and support programs for educational and financial institutions. Over time, this model should result in an increased number of franchisors and franchisees, which would increase the impact that franchising has on the Croatian economy (number of directly and indirectly employed, revenue, number of locations, etc.).

\section{METHODOLOGY}

This paper presents the results of a qualitative longitudinal research, that is, continuation of research entitled "Perspectives of development of franchising in Croatia", which was conducted in 2,006 by The Franchise Center of Center for Entrepreneurship in Osijek, Croatia. In that period, "Entrepreneurial Croatia a USAID SME support project in Croatia cofinanced organization of three workshops on franchising targeting (1) lawyers interested in providing consultant services in franchising; (2) bankers interested in providing financial support for franchisees and (3) SME consultants interested in providing counseling services to franchisees and franchisors. Each of the workshops was followed by a focus group discussion and survey, based on predefined open questions designed to analyze the macro environmental factors (political, economic, social and technological) influencing the development of franchising in Croatia. Total number of participants in the focus group discussions and survey was 45 , with 15 representatives of each targeting group of professionals (Alon et al., 2010). Longitudinal research results presented in this paper are based on repeated measurement of perceptions about the perspectives of development of franchising in Croatia in 2014 with representatives of the same population (lawyers, bankers and consultants for small and medium enterprises and franchise experts), using the same questionnaire with predefined questions, which make up the backbone of discussion between the participants of the focus group. When analyzing the research results of both focus group discussions and questionnaire results, the level 
of overlap in attitudes and perceptions of individual groups was identified, as well as newly identified answers and inputs to those previously identified in 2006 research. The overall results of this research were presented in a form of PEST analysis and compared with the results of the 2006 research aiming to detect changes (improvements / deterioration) in individual areas of the research political, economic, legal and technologic factors of influence on the development of franchising in Croatia. Based on the detected changes, conclusions and policy recommendations were identified. The research results in 2014 represent the attitudes of 15 lawyers, 15 bankers and ${ }_{15} \mathrm{SME}$ and franchise experts (in total 45 participants).

\section{RESEARCH RESULTS}

The research results in 2014, confirm a high level of overlap in attitudes and perceptions of representatives of key stakeholders (lawyers, bankers and SME and franchise experts) about the existence and influence of main operational challenges influencing the development of franchising in Croatia (Table 2.).

Table 2.: Comparison of major opportunities and threats for franchising development in Croatia identified in 2006 and 2014

\begin{tabular}{|c|c|c|c|}
\hline & Lawyers & Bankers & Franchise experts \\
\hline $\begin{array}{l}\text { Opportunities } \\
\text { identified } \\
\text { in } \\
2006\end{array}$ & $\begin{array}{l}\text { - development of the } \\
\text { service industries } \\
\text { sector; } \\
\text { - insufficient } \\
\text { awareness of } \\
\text { franchising as a } \\
\text { business model }\end{array}$ & $\begin{array}{l}\text { customers } \\
\text { increasingly focus } \\
\text { on quality service } \\
\text { and quality control; } \\
\text { - market still not } \\
\text { saturated by this } \\
\text { business concept; }\end{array}$ & $\begin{array}{l}\text { - country in } \\
\text { transition economy; } \\
\text { - incentives } \\
\text { for franchise } \\
\text { development; } \\
\text { - Croatia facing EU } \\
\text { accession }\end{array}$ \\
\hline $\begin{array}{l}\text { Opportunities } \\
\text { identified } \\
\text { in } \\
\mathbf{2 0 1 4}\end{array}$ & $\begin{array}{l}\text { insufficient } \\
\text { awareness of } \\
\text { franchising as a } \\
\text { business model } \\
\text { undeveloped } \\
\text { franchising market; } \\
\text { - Croatia as a new } \\
\text { market in EU }\end{array}$ & $\begin{array}{l}\text { undeveloped } \\
\text { franchising market; } \\
\text { - brand preference } \\
\text { among domestic } \\
\text { market; }\end{array}$ & $\begin{array}{l}\text { - undeveloped } \\
\text { franchising market; } \\
\text { - EU accession }\end{array}$ \\
\hline
\end{tabular}




\begin{tabular}{|c|c|c|c|}
\hline & Lawyers & Bankers & Franchise experts \\
\hline $\begin{array}{l}\text { Threats } \\
\text { identified } \\
\text { in } \\
2006\end{array}$ & $\begin{array}{l}\text { lack of } \\
\text { governmental and } \\
\text { banking sector } \\
\text { support; } \\
\text { - insufficient } \\
\text { protection of } \\
\text { franchisors' rights; } \\
\text { - frequent regulation } \\
\text { changes; } \\
\text { - insecurity of } \\
\text { conducting business } \\
\text { and debt collection } \\
\text { due to slow justice } \\
\text { system }\end{array}$ & $\begin{array}{l}\text { slow legal system; } \\
\text { low TEA index; } \\
\text { mentality }\end{array}$ & $\begin{array}{l}\text { - low attractiveness of } \\
\text { Croatian market to } \\
\text { foreign franchisors, } \\
\text { - lack of expertise and } \\
\text { experts; } \\
\text { - Croatia facing EU } \\
\text { accession } \\
\text { - lack of adequate } \\
\text { knowledge on } \\
\text { franchising }\end{array}$ \\
\hline $\begin{array}{l}\text { Threats } \\
\text { identified } \\
\text { in } \\
2014\end{array}$ & $\begin{array}{l}\text { - insufficient } \\
\text { protection of } \\
\text { franchisors rights; } \\
\text { - frequent regulation } \\
\text { changes; } \\
\text { - insecurity of } \\
\text { conducting business } \\
\text { and debt collection } \\
\text { due to slow legal } \\
\text { system; } \\
\text { - low purchasing } \\
\text { power; } \\
\text { - bad economic } \\
\text { condition }\end{array}$ & $\begin{array}{l}\text { - slow legal system; } \\
\text { - low purchasing } \\
\text { power; } \\
\text { - small and } \\
\text { undeveloped } \\
\text { market; } \\
\text { - administrative } \\
\text { barriers for doing } \\
\text { business; } \\
\text { - high taxes }\end{array}$ & $\begin{array}{l}\text { - lack of adequate } \\
\text { knowledge on } \\
\text { franchising; } \\
\text { - slow legal system; } \\
\text { - banks unwilling to } \\
\text { support franchising; } \\
\text { - lack of intellectual } \\
\text { property } \\
\text { - protection; } \\
\text { - bad economic } \\
\text { condition; } \\
\text { - lack of } \\
\text { entrepreneurial } \\
\text { capacity for coping } \\
\text { with challenges in } \\
\text { the environment } \\
\text { and meeting } \\
\text { franchisors' } \\
\text { expectations; } \\
\text { - franchising as } \\
\text { legally unregulated } \\
\text { area of doing } \\
\text { business; } \\
\text { low level of business } \\
\text { discipline and } \\
\text { affirmative business } \\
\text { culture }\end{array}$ \\
\hline
\end{tabular}

Source: Authors'.

Consensus of attitudes was achieved in identification of the following obstacles: (1) slow, inconsistent and insecure legal system with frequent regulation changes and high level of taxation; (2) insufficient protection of franchisors' rights, especially in the field of intellectual property protection; (3) poor economic environment, including low purchasing power of domestic population. On the organizational level, consensus of attitudes was achieved in the identification of insufficient knowledge on the franchise model and the opportunities it provides. Additionally, representatives of SME and franchise experts emphasized the obstacles related to organizational limitations of companies and lack of personal entrepreneurial skills managers in coping with exter- 
nal and internal challenges imposed by implementation of franchising as a business model. Lack of entrepreneurial capacity for coping with challenges in the environment and meeting franchisors' expectations, low business discipline and lack of affirmative business culture are newly identified challenges in 2014, research, which did not appear as relevant in the research conducted in 2013. It is important to emphasize that all three groups of stakeholders confirmed already identified opportunities in research conducted in 2006 that are accession to EU and underdevelopment of franchising in Croatia. Other identified challenges in 2006 that are still persistent in its influence in 2014 are: lack of franchising legal regulations and insufficient knowledge of franchising as a business model. However, lack of franchising legal regulations hasn't been grouped in any of the most relevant obstacles, since franchising related business practice confirmed that this could be compensated by highly efficient general legal framework. In case of Croatia, it is argued that legally regulated franchising would not increase significantly the level of implementation of franchising, because of the wider inefficient, insecure and slow legal framework for doing business that influences entrepreneurial activity in general. The influence of the identified obstacles on the level of entrepreneurial activity and in Croatia is confirmed by the results of major international research studies that collect and analyze the quality of business environment. World Bank survey Doing Business (2013) identifies main problems related to the quality of business environment in Croatia as following: getting construction permits, protecting investors, registering property, trading across borders, resolving insolvency. The most problematic factors for doing business in Croatia, according to Global Competitiveness Report (2013) are: low efficiency of public administration, corruption, instability of policies, tax rates, restrictive labor legislation, access to financial resources, tax regulations and poor work ethics of national workforce. According to the results of Global Entrepreneurship Monitor (GEM) research, the main problems for raising the level of entrepreneurial activity in Croatia are identified in the area of entrepreneurship supporting government policies, regulatory framework, attitude towards growing companies and entrepreneurs in general and interest in innovation from business perspective (Singer et al., 2012). All of the mentioned international studies confirm the existence of following characteristics on business environment in Croatia: administrative obstacles (long and expensive procedures for startup and termination of an enterprise), inefficiency of the judiciary system, long ownership registration procedures, low focus on entrepreneurial education, poor perception of entrepreneurship as a desired career choice and underdevelopment of nonformal financing forms in business ventures startup. Research participants (both in 2006 and 2014) were expected to identify political / legal, economic, social and technological factors (PEST analysis) influencing the development of franchising business model in Croatia. Collected answers in 2014, were systemized and presented in a form of matrix overview and compared to the results of the research conducted in 2006 (Table 3.). 
Table 3.: PEST analysis of the mayor environmental factors influencing franchise development in Croatia

\begin{tabular}{|c|c|c|}
\hline & $\begin{array}{c}\text { Research results } \\
2006\end{array}$ & $\begin{array}{c}\text { Research results } \\
2014\end{array}$ \\
\hline $\begin{array}{l}\text { Political } \\
\text { factors }\end{array}$ & $\begin{array}{l}\text { - no registry of movables } \\
\text { which could be used as a } \\
\text { collateral; } \\
\text { - } \text { bureaucracy; } \\
\text { - insufficient protection of } \\
\text { franchisors' rights; } \\
\text { - lack of legal experience in } \\
\text { regulating franchise as a } \\
\text { business concept; } \\
\text { - insufficient arbitration } \\
\text { usage; } \\
\text { - possibility of sudden } \\
\text { regulatory interventions by } \\
\text { the legislators; } \\
\text { - franchise agreement } \\
\text { nonexistent in state } \\
\text { regulations; } \\
\text { - inadequate intellectual } \\
\text { property rights protection; } \\
\text { - lack of lawyers who are highly } \\
\text { specialized and trained for } \\
\text { franchise business model }\end{array}$ & $\begin{array}{l}\text { - slow and inefficient legal } \\
\text { system with consistent } \\
\text { changes in laws and tax } \\
\text { regulations; } \\
\text { - problems in collection of due } \\
\text { receivables; } \\
\text { - inadequate and too slow } \\
\text { intellectual property rights } \\
\text { protection; } \\
\text { - bureaucracy; } \\
\text { - lack of legal experience in } \\
\text { regulating franchise as a } \\
\text { business concept; } \\
\text { - franchise agreement } \\
\text { nonexistent in state } \\
\text { regulations; } \\
\text { - national classification of } \\
\text { industries not updated; } \\
\text { - corruption; } \\
\text { - no registry of franchising } \\
\text { networks; } \\
\text { - potential of franchising } \\
\text { for development of } \\
\text { entrepreneurship not } \\
\text { recognized at the policy level; } \\
\text { non flexible labor force } \\
\text { market and regulations; } \\
\text { - lack of vision of economic } \\
\text { development of Croatia at } \\
\text { policy level }\end{array}$ \\
\hline Economic factors & $\begin{array}{l}\text { - Croatia is not recognized as a } \\
\text { taxfriendly market; } \\
\text { - small market; } \\
\text { - lack of public institution } \\
\text { support; } \\
\text { - unwillingness of banks for } \\
\text { participating in franchise } \\
\text { purchase financing; } \\
\text { - low purchasing power with } \\
\text { relatively high franchise } \\
\text { product / service prices; } \\
\text { - insufficient economic } \\
\text { development; } \\
\text { - high unemployment rate; } \\
\text { - lack of adequate financial } \\
\text { tools }\end{array}$ & $\begin{array}{r}\text { too expensive labor force; } \\
\text { decrease in purchasing power as } \\
\text { a result of crisis, poverty; } \\
\text { long time needed for return of } \\
\text { investment; } \\
\text { lack of structural reforms of the } \\
\text { economy and its influence in } \\
\text { decrease of GDP; } \\
\text { too small market; } \\
\text { low capital potential of } \\
\text { investors; } \\
\text { banks not willing to finance } \\
\text { startups; } \\
\text { unwillingness of banks for } \\
\text { participating in franchise } \\
\text { purchase financing; } \\
\text { lack of nontraditional financial } \\
\text { products in the market; }\end{array}$ \\
\hline
\end{tabular}




\begin{tabular}{|c|c|c|}
\hline & $\begin{array}{c}\text { Research results } \\
2006\end{array}$ & $\begin{array}{c}\text { Research results } \\
2014\end{array}$ \\
\hline $\begin{array}{l}\text { Social } \\
\text { factors }\end{array}$ & $\begin{array}{l}\text { - mentality (infringements of } \\
\text { business agreements, quick } \\
\text { profit expectations); } \\
\text { - low standard of living; } \\
\text { - lack of knowledge; } \\
\text { - high indebtedness of the } \\
\text { population; } \\
\text { - atmosphere of mistrust; } \\
\text { - intellectual property rights } \\
\text { violations }\end{array}$ & $\begin{array}{l}\text { - lack of knowledge on } \\
\text { franchising; } \\
\text { - refraining from investment } \\
\text { fear of future; } \\
\text { - high rate of unemployment; } \\
\text { - no tradition of franchising; } \\
\text { - mistrust to foreign } \\
\text { franchisors; } \\
\text { - fear of longterm binding by } \\
\text { agreement; } \\
\text { - fear of undertaking } \\
\text { entrepreneurial activity; } \\
\text { - huge differences in market } \\
\text { potential of different parts of } \\
\text { Croatia; } \\
\text { - aversion to accepting new } \\
\text { ways of doing business } \\
\text { - lack of knowledge } \\
\text { and willingness for } \\
\text { selfemployment }\end{array}$ \\
\hline Technological factors & $\begin{array}{l}\text { - lack of adequate knowledge; } \\
\text { - low R\&D investment rates; } \\
\text { - bad infrastructure; } \\
\text { - low level of technological } \\
\text { education; } \\
\text { - underdevelopment; } \\
\text { - technology obsolescence and } \\
\text { low rate of new technology } \\
\text { trends' adoption }\end{array}$ & $\begin{array}{l}\text { numerous regulations which } \\
\text { increase insecurity; } \\
\text { - undeveloped industrial } \\
\text { sector; } \\
\text { - decrease in production of } \\
\text { different goods which directs } \\
\text { entrepreneurs to import } \\
\text { many ingredients in some } \\
\text { industries; } \\
\text { - low level of computer and } \\
\text { internet skills among } \\
\text { population for collecting } \\
\text { information on business } \\
\text { opportunities. }\end{array}$ \\
\hline
\end{tabular}

Source: authors'.

Political factors influencing franchising development identified in 2014 research could be divided into two groups of factors: general business related factors and franchising specific factors of influence. Comparing to research results in 2006 when most of the political factors identified were specifically linked to implementation of franchising business model in Croatia (lack of legal experience in regulating franchise as business concept, or franchise agreement nonexistent in state regulations), in 2014 most of the factors are affecting all types of businesses, regardless the business model applied. Development of franchising, therefore, like any other kind of doing business in Croatia is strongly influenced by slow and inefficient legal system with consistent changes in laws and tax regulations, inadequate and too slow intellectual property rights protection, bureaucracy, nonflexible labor force market and regulations, lack of vision of economic development of Croatia at policy level, etc. Analysis of economic factors influencing the development of franchising in 2014 
identified even less favorable economic conditions than those coming from 2006 research results. Economic factors have all been unsupportive for franchising development, and again, being more generally linked and unfavorable to all businesses, not just franchise networks. The most commonly identified and emphasized economic factors are: too expensive labor force, decreased market potential due to low purchasing power and poverty of local population, lack of structural reforms in Croatia and so on. Social factors identified in 2014 research are deeply rooted in mentality and longterm period of crisis and its consequences on entrepreneurial environment in Croatia. In that context, most important social factors identified in 2014, research are: refraining from investment due to uncertain future, fear of longterm binding agreements and huge differences in market potential of different parts of Croatia. Technological factors identified in 2014 research represent highest deviation from 2006 research results, among 4 groups of factors. Lack of adequate knowledge, as a consequence of low level of technological education in Croatia and low R\&D investment rates are still persistent identified factors influencing franchising and other business forms. However, infrastructural preconditions could be identified as rather supportive as unsupportive factor for business development in Croatia. Newly identified technological factors in 2014, research are: undeveloped industrial sector, importoriented economy and highly regulated business environment which increases the level of insecurity and complexity in the market.

\section{CONCLUSIONS AND POLICY RECOMMENDATIONS}

The research conducted in 2014 and described in this paper aimed on identification of barriers for development of franchising in Croatia. This research represents continuation of research conducted in 2006, what enabled identification of changes (improvements / deteriorations) in the franchising environment in Croatia from 2006 2014. The identified obstacles in 2014 could be divided in two categories: (1) franchising specific barriers and (2) general business related obstacles for doing business in Croatia. Franchising specific obstacles are consistent to those identified in 2006 research: the absence of franchising legislative regulations; lack of banking franchise purchase (co)financing programs; lack of accompanying advisory and informational support for franchising, lack of knowledge on franchising. The general business related obstacles were additionally identified and emphasized in 2014 research by majority of focus group and survey participants. High level of consensus of attitudes was achieved in identification of issues related to legal system (slow, inconsistent and insecure, with frequent regulation changes), taxation, intellectual property rights protection and poor market potential resulting from low purchasing power of domestic population. The most of identified obstacles through this qualitative research are of general nature, affecting the activities of all business entities, regardless the model of doing business applied. The existence of those obstacles in 
Croatian business environment is strongly confirmed by the research results of all major international studies conducted in Croatia in the last decade (Doing Business, Global Competitiveness Report and Global Entrepreneurship Monitor). Based on the fact that franchising specific elements of the business environment are persistent in their existence (identified in 2006 research, still present in 2014) and make negative influence of franchising, the policy recommendations based on 2006 research results are still valid and relevant: creation of legislative framework based on the best practices of EU countries; organization of a promotional campaign aimed at informing the public about the benefits of franchising; cofinancing the costs of development of franchising networks for growing companies in Croatia; cofinancing education on franchising for startups and growing companies; strengthening infrastructural support for development of franchising through organizing and cofinancing education on franchising for lawyers, financial institutions, business advisors and representatives of business support institutions. The level of support for franchising activity in business environment in Croatia is highly dependent on successful implementation of policy recommendations for raising the level of entrepreneurial activity in general, identified by all major international studies. The most important and for the results of this research relevant policy recommendations in that field are: removing administrative obstacles and lengthy procedures for conducting entrepreneurial activities, increasing the efficiency of the judiciary system, a stronger focus on entrepreneurship education and developing informal forms of financing of business ventures. Without solving these problems it is unrealistic to expect high growth of entrepreneurial and franchising activities in Croatia in near future. 


\section{REFERENCES}

Alon I., "Global Franchising and Development in Emerging and Transitioning Markets", Journal of Macromarketing, 24, (2), (2004):156-167

Alon I., "Service Franchising A Global Perspective", (Springer: USA), (2006)

Alon, I., Alpeza, M., Erceg, A., "Franchising in Croatia”, book chapter Alon, I., (ed.), Franchising globally: innovation, learning and imitation, Palgrave Macmillan: New York), (2010): 138-154

Alpeza, M, Peric, J., Soltic, A., "The Role of Creativity and Innovation in Implementation of Franchising Business Model in Croatia", paper presented at 32nd International Conference on Entrepreneurship and Innovation Podim Potentials of Creative Industries, April 45, Maribor, Slovenia, (2012)

Bradach, J., "Using the plural form in the management of restaurant chains", Administrative Science Quarterly, 42 (2), (1997): 276-3०3

Caffey, A. A., 8 Reasons Not to Franchise Your Business, All Business, Available from http://www. allbusiness.com/franchises/franchisingyourbusiness/125825931.html, [Accessed: 11th January 2014], (2009)

Carney, M., Gedajlovic, E, "Vertical Integration in Franchise Systems: Agency Theory and Resource Explanations", Strategic Management Journal, 12, (1991): 607-629

Castrogiovanni, G. J., Justis, R. T., "Franchising configurations and transitions", Journal of Consumer Marketing, Vol. 15 (2), (1998): 170-190

Combs, J. G., Castrogiovanni, G. J. , "Franchisor Strategy: A Proposed Model and Empirical Test of Franchise versus Company Ownership", Journal of Small Business Management, 32 (2), (1994): 37-4.8

Combs, J. G., Ketchen, D. J., Short, J. C., "Franchising Research: Major Milestones, New Directions, and Its Future within Entrepreneurship", Entrepreneurship Theory and Practice, Special Issue: New Directions in Franchising Research, 35 (3), (2011): 413-4.25

Combs, J. G., Michael, S. C., Castrogiovanni, G. J., "Franchising: A Review and Avenues to Greater Theoretical Diversity", Journal of Management, 3० (6), (2004): 907-931

DiazBernardo, R., "The Franchising Decision: The Perspective Of The Franchisee in The Hospitality Industry", International Business \& Economics Research Journal, 8 (8), (2009): 61-64

Dwivedy, R., "Franchising Indeed Could Become the Business Ambassador of World Peace through Global Economic Prosperity", Franchising World, 34, (3), (2002): 17

Eisenhardt, K., "Agency Theory: An Assessment and Review", The Academy of Management Review, 14. (1), (1989): $57^{-} 74$

Emerson, R,, "Franchising and the Collective Rights of Franchisees", Vanderbilt Law Review, 43, (1990): $15^{2} 3-15^{32}$

Erceg, A., "Franšizni poslovni model i njegov utjecaj na strategije rasta poduzetnika (Franchising and its Influence on Entrepreneurs' Growth Strategies), doctoral thesis defended at Faculty of Economics in Osijek, J.J. Strossmayer University in Osijek, Croatia, (2012)

European Franchise Federation, "Franchise Statistics for 20 Countries in Europe", Available from http:// www.efffranchise.com, [Accessed: 10th May 2013], (2010)

Fulop, C., "History and Development", in Lashley, C., Morrison, A., (eds.), Franchising Hospitality Services (Butterworth Heinemann: England), (2000) 
Gillis W., Gastrogiovanni G. J., "The Franchising Business Model: An Entrepreneurial Growth Alternative", International Entrepreneurship and Management Journal, 8 (1), (2012): 75-98

Glujic, D., Fransizni ugovor (Franchising agreement), Pravo i management, enovine, Available from www. dashofer.hr/print.phtml?cid=33०3, [Accessed: 15th March 2014], (2008)

Hoffman, R. C., Preble, J. F., "Global Franchising: Current Status and Future Challenges", Journal of Services Marketing, 18 (2), (2004): 101-113

Kukec, Lj., Izazovi primjene fransiza kao modela sirenja poslovanja u Hrvatskoj, (The challenges of Applying the Franchising as a Model of Business Expansion in Croatia) master thesis defended at Faculty of Economics in Osijek, J.J. Strossmayer University in Osijek, Croatia, (2009)

Lafontaine, F., Kaufmann, P. J., "The Evolution of Ownership Patterns in Franchise Systems", Journal of Retailing, 70, (1994): 97-113

Maitland, I, "Franchising A Practical Guide for Franchisors and Franchisees", (Management book: England), (2000)

Mesenbourg, T., "Franchise statistics 2007 Highlights of the Economic Census report", Available from: https://www.census.gov/econ/census/ppt/2007ec_franchise.ppt, [Accessed: 15th February 2014], (2010)

Mlikotin Tomic, D., "Ugovor o franchisingu i pravo konkurencije" (Franchising Agreement and competition law), Pravo u gospodarstvu, 39 (4), (2000): 54- 73

Ministarstvo poduzetnistva i obrta, "Poduzetnicki implus 2013 Program poticanja poduzetnistva i obrta" (Entrepreneurship impulse 2013 Program for fostering entrepreneurship and crafts), Available from: http:// www.minpo.hr/UserDocsImages/73.\%20\%2011.pdf, [Accessed: 15th March 2014], (2013)

Nieman, G., Barber, J., "How to Franchise Your Own Business", (IDG Books: South Africa), (1987)

Norton, S. W., "Franchising, Brand Name Capital, and the Entrepreneurial Capacity Problem", Strategic Management Journal, (Special Issue: Strategy Content Research), 9, (1988): 105-114

Oxenfeldt,A. R., Kelly, A. O., "Will Successful Franchise Systems Ultimately Become Whollyowned Chains?" Journal of Retailing, 44, (1968): 69-83

Pavlin, I., Franchising in Slovenia, Report on training and support structures for young SMEs in Slovenia, (2008): $15-108$

Rubin, P. H., "The Theory of the Firm and the Structure of the Franchise Contract", Journal of the Law and Economics, 21 (1), (1978): 223-233

Sanghavi, N., "Franchising as a Tool for Small Medium Sized Enterprises (SME) Development in Transitional Economies The case of the Central European Countries", Management Research News, 21 (11), (1998): 35-44

Schwab, K., ed., "The Global Competitiveness Report 2013 -2014: Full Data Edition", World Economic Forum, Available ad http://www3.weforum.org/docs/WEF_GlobalCompetitivenessReport_201314.pdf, [Accessed: 10th February 2014], (2013)

Seid, M., "Expanding One's Business through Franchising", Available from: http://www.msaworldwide. com/franchising/whatisfranchising/ [Accessed: 10th January 2014]., (2002)

Selnew, A. C., "Introduction to Franchising, 2nd edition", (Minnesota Department of Trade and Economic Development Briggs and Morgan, P.A.: USA), (1998)

Shane, A. S., "From Ice Cream to the Internet: Using Franchising to Drive the Growth and Profits of Your Company", (Prentice Hall: USA). (2005) 
Shane, A. S., Foo, M., "New Firm Survival, Institutional Explanations for New Franchisor Mortality", Management Science, 45 (2), (1999): 142-159

Siggel, E., Maisonneuve, P., Fortin, E., The Role of Franchising in African Economic Development, paper presented at the 1 $7_{\text {th }}$ Annual International Society of Franchising Conference, San Antonio, Texas, February, (2003): 14-16

Singer, S., Sarlija, N., Pfeifer, S., Oberman Peterka, S., "What makes Croatia a (non) entrepreneurial country?", GEM Croatia 20022011, (Zagreb: CEPOR SMEs \& Entrepreneurship Policy Centre), (2012)

Spinelli, S., Rosenberg, M., Birley, S., "Franchising Pathway to Wealth Creation", (USA: FT Prentice Hall), (2004)

Stanworth, J., "Franchising and the Franchise Relationship", International Journal of Retail Distribution and Consumer Research, 1 (2), (1991): 175-199

Stanworth, J., Purdy, D., "Franchising Your Business", Lloyds TSB IFRC, England, (2002):148

World Bank., Doing Business 2013: Smarter Regulations for Small and MediumSize Enterprises. Washington, DC: World Bank Group, Available at http://www.doingbusiness.org/ /media/GIAWB/ Doing\%2oBusiness/Documents/AnnualReports/English/DB13fullreport.pdf, [Accessed: 10th February 2014], (2013) 